\title{
GENETIC EVIDENCE FOR RECENT SPREAD OF SPRINGSNAILS (HYDROBIIDAE: PYRGULOPSIS) ACROSS THE WASATCH DIVIDE
}

\author{
Hsiu-Ping Liu ${ }^{1}$, Peter Hovingh ${ }^{2}$, and Robert Hershler 3,4
}

\begin{abstract}
The biogeographic history of aquatic organisms in relation to the Wasatch Mountains divide (which separates the eastern Great Basin and upper Colorado River basin in Utah) has been little studied aside from a large body of work on fishes. Pyrgulopsis kolobensis is a small springsnail that is distributed (in the eastern portion of its range) along the western flanks of the Wasatch Mountains, with a single population occurring just across the Wasatch divide in Strawberry Valley. Here we analyze the genetic structure of this species across the Wasatch divide (using the mtCOI gene) to discriminate between alternative hypotheses that explain this distributional pattern. The 6 P. kolobensis populations that we sampled were resolved as a single, weakly supported and shallowly structured clade in a Bayesian analysis. Specimens from Strawberry Valley shared a unique haplotype and differed from the other populations by $0.3 \%-0.8 \%$ sequence divergence, suggesting a geologically recent split that well postdated the Miocene inception of the Wasatch divide. This result is consistent with a hypothesis (supported by geological evidence) that the Strawberry Valley population became isolated during the late Quaternary as a result of a headwater transfer across the Wasatch divide. Our findings parallel a recent phylogeographic study of regional pebblesnails (Fluminicola coloradensis) and contrast with the prevailing pattern in fishes, which generally do not cross the Wasatch divide. The ability of these 2 snail species to penetrate into upland headwater habitats appears to be the key to their success in crossing the Wasatch (and other) drainage divides.
\end{abstract}

Resumen.-La historia biogeográfica de los organismos acuáticos en relación con la bifurcación de las Montañas Wasatch (que separan la Great Basin este y la cuenca alta del Río Colorado en Utah) ha sido poco estudiada, además del extenso trabajo que se ha realizado con peces. Pyrgulopsis kolobensis es un pequeño caracol de agua dulce que se distribuye en la parte oriental de la cordillera, a lo largo de los flancos occidentales de las montañas Wasatch, con una sola población que emerge al otro lado de la bifurcación Wasatch en Strawberry Valley. En este estudio analizamos la estructura genética de esta especie a lo largo de la bifurcación Wasatch (utilizando el gen mtCOI) para discriminar entre las hipótesis alternativas que explican este patrón en la distribución. Las 6 poblaciones de $P$. kolobensis que muestreamos fueron reconocidas como un único clado, débilmente apoyado y superficialmente estructurado con un análisis bayesiano. Los especímenes de Strawberry Valley comparten un haplotipo único y difieren de las otras poblaciones por una secuencia divergente de $0.3 \%-0.8 \%$, lo que sugiere una división geológica reciente, posterior al Mioceno, fecha de origen de la bifurcación Wasatch. Este resultado es consistente con la hipótesis (apoyada por evidencia geológica) de que la población de Strawberry Valley se aisló durante el Cuaternario tardío como resultado del nacimiento de agua a lo largo de la bifurcación Wasatch. Nuestros hallazgos se realizaron en paralelo con un reciente estudio filogeográfico de los caracoles regionales (Fluminicola coloradensis) y contrastan con el patrón predominante en peces, que generalmente no cruzan la bifurcación Wasatch. La capacidad de estas 2 especies de caracoles para entrar en los hábitats de los nacimientos de agua de tierras altas parece ser la clave de su éxito al cruzar los drenajes de las bifurcaciones Wasatch (y otras).

The 370-km-long, north-south-trending Wasatch Mountains separate the eastern Great Basin and upper Colorado River basin in Utah. Smith (1978) identified this mountain range as a strong dispersal barrier for fishes based on the limited species overlap across it. Phylogeographic studies of those fishes that are distributed (naturally) on both sides of the Wasatch Mountains drainage divide (referred to herein as the Wasatch divide) have shown that the (intraspecific) lineages in these 2 areas are not closely related to each other
(Catostomus discobolus, Hopken et al. 2013; Oncorhynchus clarkii, Loxterman and Keeley 2012; Rhinichthys osculus, Oakey et al. 2004, Smith and Dowling 2008), providing additional evidence that the Wasatch divide functions as a strong dispersal barrier for this group. However, the biogeographic history of other obligately aquatic organisms in relation to the Wasatch divide has not been investigated aside from a recent study which showed that pebblesnails (Fluminicola coloradensis) share haplotypes and are not significantly

\footnotetext{
${ }^{1}$ Department of Biology, Metropolitan State University of Denver, Denver, CO 80217

2721 Second Avenue, Salt Lake City, UT 874103

${ }^{3}$ Department of Invertebrate Zoology, Smithsonian Institution, Box 37012, Washington, DC 20013-7012.

${ }^{4}$ E-mail: hershlerr@si.edu
} 


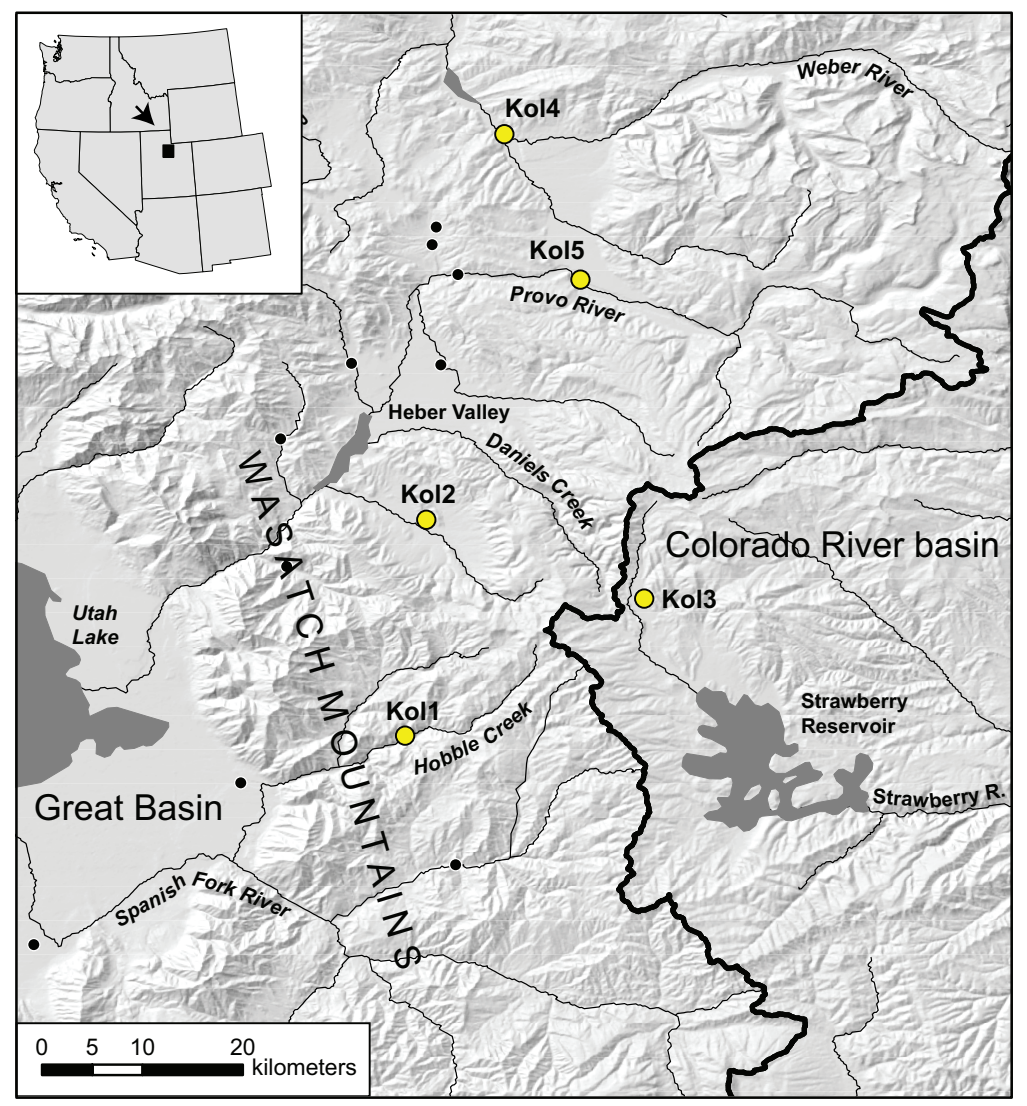

Fig. 1. Pyrgulopsis kolobensis collection localities in the Wasatch Mountains area (Kol 1-5). The thickened black line delineates the Wasatch divide and the small black circles show the location of unsampled populations (data from Hershler 1998). The arrow in the inset shows the location of the Bear River drainage population (P162).

structured genetically across this barrier (Liu et al. 2013).

The Toquerville springsnail (Pyrgulopsis kolobensis) is a small, gill breathing caenogastropod that is widely distributed in the eastern Great Basin and several adjacent areas (Fig. 54 in Hershler 1998). In the eastern portion of its range, P. kolobensis is distributed along the Wasatch Front and its canyons, with one population occurring just across the Wasatch divide in Strawberry Valley (Fig. 1, Kol3). This is the only record of this large genus (139 species; Hershler et al. 2014b) in the upper Colorado River basin. Several alternative scenarios can be envisaged to explain this transmontane distributional pattern. First, the Wasatch Mountains may separate distantly related $P$. kolobensis lineages (i.e., not forming a monophyletic group) as has been documented in several fishes (see above). We note in this context that morphologically cryptic species have been detected in several other springsnails that range across multiple drainage basins (e.g., $P$. micrococcus; Hershler et al. 2013). Second, this distributional pattern could be the product of vicariance associated with the inception of the Wastach divide, which dates minimally to the early to middle Miocene (10-12 Ma; Bryant el al. 1989). Third, the Strawberry Valley population could have become isolated as a consequence of a subsequent headwater transfer across the Wasatch divide in which case it would be expected to form a distinct lineage that is little differentiated from geographically proximal populations in the eastern Great Basin (consistent with a split during the Quaternary). This hypothesis is supported by geologic evidence that the western portion of Strawberry Valley drained (eastward) into the Provo River basin through Daniels Canyon 


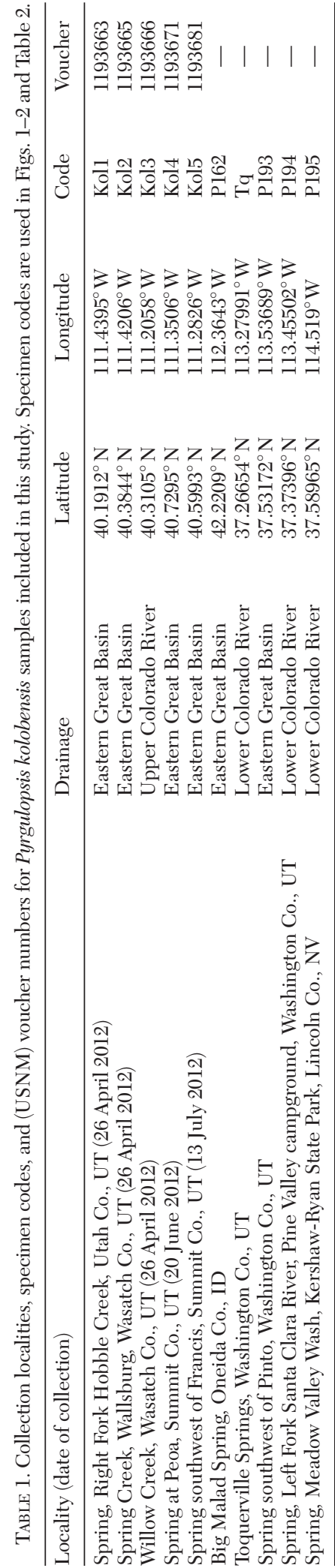

for some time prior to late Quaternary faulting which severed this connection (Nelson and Krinsky 1982, Sullivan et al. 1988). Fourth, the Strawberry Valley population could have been founded by anthropogenic means and thus would be expected to bear the genetic signature of very recent separation (e.g., sharing of haplotypes with populations across the Wasatch Divide). The valley is a popular stop for anglers and there is a long history of introduction of nonnative fishes into Strawberry Reservoir, including several species that are distributed naturally in the eastern Great Basin (Catostomus ardens, Gila atraria; Sigler and Sigler 1996, Lentsch et al. 2001). We note in this context that the New Zealand mudsnail (Potamopyrgus antipodarum), whose spread in the West has been attributed in part to bait bucket release and other fisherman activities, was recently discovered in the Strawberry River (Vinson 2004). There is also a long history of artificial surface water transfers across the Wasatch divide from Strawberry Valley beginning in the late 1800s (La Rue 1916, Nelson 1997) which could have facilitated spread of $P$. kolobensis into the latter, although this would have required upflow migration in man-made canals. Herein we analyze the genetic structure of $P$. kolobensis across the Wasatch divide using mtCOI sequence data to discriminate among these competing hypotheses.

\section{Methods}

For this study we collected (in 2012) specimens of $P$. kolobensis from Strawberry Valley and 4 populations on the other side of the Wasatch divide in the Provo and Weber River drainages (Fig. 1, Koll-5). We also included in our analyses previously published sequences from conspecific populations located in other parts of the eastern Great Basin (Hershler and Liu 2004a, 2004b, 2008) and the lower Colorado River basin (Hurt 2004, Liu and Hershler 2005, Hershler and Liu 2008). Samples were collected with a fine hand sieve and preserved in concentrated $(90 \%)$ ethanol in the field. Voucher material was deposited in the Smithsonian Institution's National Museum of Natural History (USNM) collection. Five specimens from each sample were sequenced for mtCOI. Genomic DNA was extracted from entire snails using a CTAB protocol (Bucklin 1992); each specimen was analyzed for mtDNA individually. 
TABLE 2. COI haplotypes detected in Pyrgulopsis kolobensis ("Wasatch clade"). $n=$ number of specimens.

\begin{tabular}{|c|c|c|c|c|c|c|c|c|c|c|c|}
\hline \multirow[b]{2}{*}{ Haplotype } & \multirow{2}{*}{$\begin{array}{c}\text { GenBank } \\
\text { accession number }\end{array}$} & \multicolumn{10}{|c|}{ Base pair position } \\
\hline & & 55 & 79 & 181 & 187 & 193 & 400 & 496 & 511 & 538 & 625 \\
\hline $\operatorname{KollA}(n=4)$ & KT248032 & $\mathrm{T}$ & A & $\mathrm{T}$ & $\mathrm{C}$ & $\mathrm{T}$ & $\mathrm{T}$ & G & G & $\mathrm{C}$ & $\mathrm{C}$ \\
\hline KollB $(n=3)$ & KT248033 & $\mathrm{T}$ & A & $\mathrm{T}$ & $\mathrm{T}$ & $\mathrm{T}$ & $\mathrm{C}$ & G & A & $\mathrm{T}$ & $\mathrm{C}$ \\
\hline $\operatorname{Kol} 2 \mathrm{~A}(n=1)$ & KT248034 & $\mathrm{T}$ & A & $\mathrm{T}$ & $\mathrm{C}$ & $\mathrm{T}$ & $\mathrm{T}$ & G & A & $\mathrm{C}$ & $\mathrm{C}$ \\
\hline Kol2B $(n=3)$ & KT248035 & $\mathrm{T}$ & A & $\mathrm{T}$ & $\mathrm{C}$ & $\mathrm{T}$ & $\mathrm{T}$ & G & A & $\mathrm{C}$ & $\mathrm{C}$ \\
\hline $\operatorname{Kol} 2 \mathrm{E}(n=1)$ & KT248036 & $\mathrm{T}$ & A & $\mathrm{T}$ & $\mathrm{C}$ & $\mathrm{C}$ & $\mathrm{T}$ & G & A & $\mathrm{C}$ & $\mathrm{C}$ \\
\hline $\operatorname{Kol} 3 \mathrm{~A}(n=5)$ & KT248037 & $\mathrm{T}$ & A & $\mathrm{T}$ & $\mathrm{T}$ & $\mathrm{T}$ & $\mathrm{C}$ & G & A & $\mathrm{T}$ & $\mathrm{T}$ \\
\hline $\operatorname{Kol} 4 \mathrm{~A}(n=5)$ & KT248038 & $\mathrm{T}$ & A & $\mathrm{C}$ & $\mathrm{T}$ & $\mathrm{T}$ & $\mathrm{C}$ & G & A & $\mathrm{T}$ & $\mathrm{C}$ \\
\hline $\operatorname{Kol} 5 \mathrm{~B}(n=1)$ & KT248039 & $\mathrm{T}$ & A & $\mathrm{T}$ & $\mathrm{T}$ & $\mathrm{T}$ & $\mathrm{C}$ & G & A & $\mathrm{T}$ & $\mathrm{C}$ \\
\hline $\operatorname{Kol} 5 \mathrm{C}(n=1)$ & KT248041 & $\mathrm{T}$ & A & $\mathrm{T}$ & $\mathrm{T}$ & $\mathrm{T}$ & $\mathrm{C}$ & A & A & $\mathrm{T}$ & $\mathrm{C}$ \\
\hline $\operatorname{Kol} 5 \mathrm{E}(n=1)$ & KT248042 & $\mathrm{T}$ & G & $\mathrm{T}$ & $\mathrm{T}$ & $\mathrm{T}$ & $\mathrm{C}$ & G & A & $\mathrm{T}$ & $\mathrm{C}$ \\
\hline $\mathrm{P} 162 \mathrm{~A}(n=3)$ & & $\mathrm{C}$ & A & $\mathrm{T}$ & $\mathrm{T}$ & $\mathrm{T}$ & $\mathrm{C}$ & G & A & $\mathrm{T}$ & $\mathrm{C}$ \\
\hline
\end{tabular}

LCO1490 (Folmer et al. 1994) and COIH 2390 (Liu et al. 2001) were used to amplify a 900-base pair (bp) fragment of COI; amplification conditions and sequencing of amplified polymerase chain reaction product followed Liu et al. (2001). Sequences were determined for both strands and then edited and aligned using SEQUENCHER ${ }^{\mathrm{TM}}$ version 5.0.1. Our molecular phylogenetic analysis also included congeners from the eastern Great Basin ( $P$. inopinata, P. plicata) and lower Colorado River basin (P. bacchus, P. morrisoni) that were shown to be closely related to $P$. kolobensis in prior molecular phylogenetic studies (Hurt 2004, Liu and Hershler 2005). The type species of the eastern North American genus Marstonia was used to root the tree (per Liu and Hershler 2005). One example of each haplotype detected in a given sample was used in our analyses. All analyses were based on 658bp aligned nucleotide sequences. Locality and collection information, sample codes, and voucher numbers for the (newly sequenced) P. kolobensis material are detailed in Table 1.

MrModeltest 2.3 (Nylander 2004) was used to obtain an appropriate substitution model (using the Akaike information criterion) and parameter values for the molecular phylogenetic analysis, which was conducted using MrBayes 3.1.2 (Huelsenbeck and Ronquist 2001). Metropolis-coupled Markov chain Monte Carlo simulations were run with 4 chains (using the model selected through MrModeltest) for 2,000,000 generations, and Markov chains were sampled at intervals of 10 generations to obtain 200,000 sample points. We used the default settings for the priors on topologies and the HKY + I + G model (Hasegawa et al. 1985) parameters selected by
MrModeltest as the best-fit model. At the end of the analysis, the average standard deviation of split frequencies was $<0.01 \quad(0.0025)$ and the Potential Scale Reduction Factor (PSRF) was 1, indicating that the runs had reached convergence. The sampled trees with branch lengths were used to generate a $50 \%$ majority rule consensus tree with the first $25 \%$ of the samples removed to ensure that the chain sampled a stationary portion.

Genetic distances within and between samples of P. kolobensis were calculated using MEGA6 (Tamura et al. 2013), with standard errors estimated by 1000 bootstrap replications with pairwise deletion of missing data. Since MEGA does not contain the HKY model that was selected by MrModELTEST, we used the uncorrected distance.

\section{RESUlTS}

New sequences were deposited in GenBank (accession numbers KT248032-248042). Ten haplotypes, differing from each other by 1-7 bp, were detected in the 25 newly sequenced specimens of $P$. kolobensis from Strawberry Valley and the 4 populations on the other side of the Wasatch divide (Table 2). One of these haplotypes (KollB) was shared by 2 populations (Koll, 1 specimen; Kol5, 2 specimens), whereas the other 9 were restricted to single populations. The single haplotype detected in the Strawberry Valley population (Kol3A) differed from haplotype KollB by 1 base pair (Table 2). The haplotype (P162A) detected in the Bear River drainage population differed from the newly reported haplotypes by $1-6$ bp (Table 2 ). Collectively the $P$. kolobensis sequences formed a poorly supported 


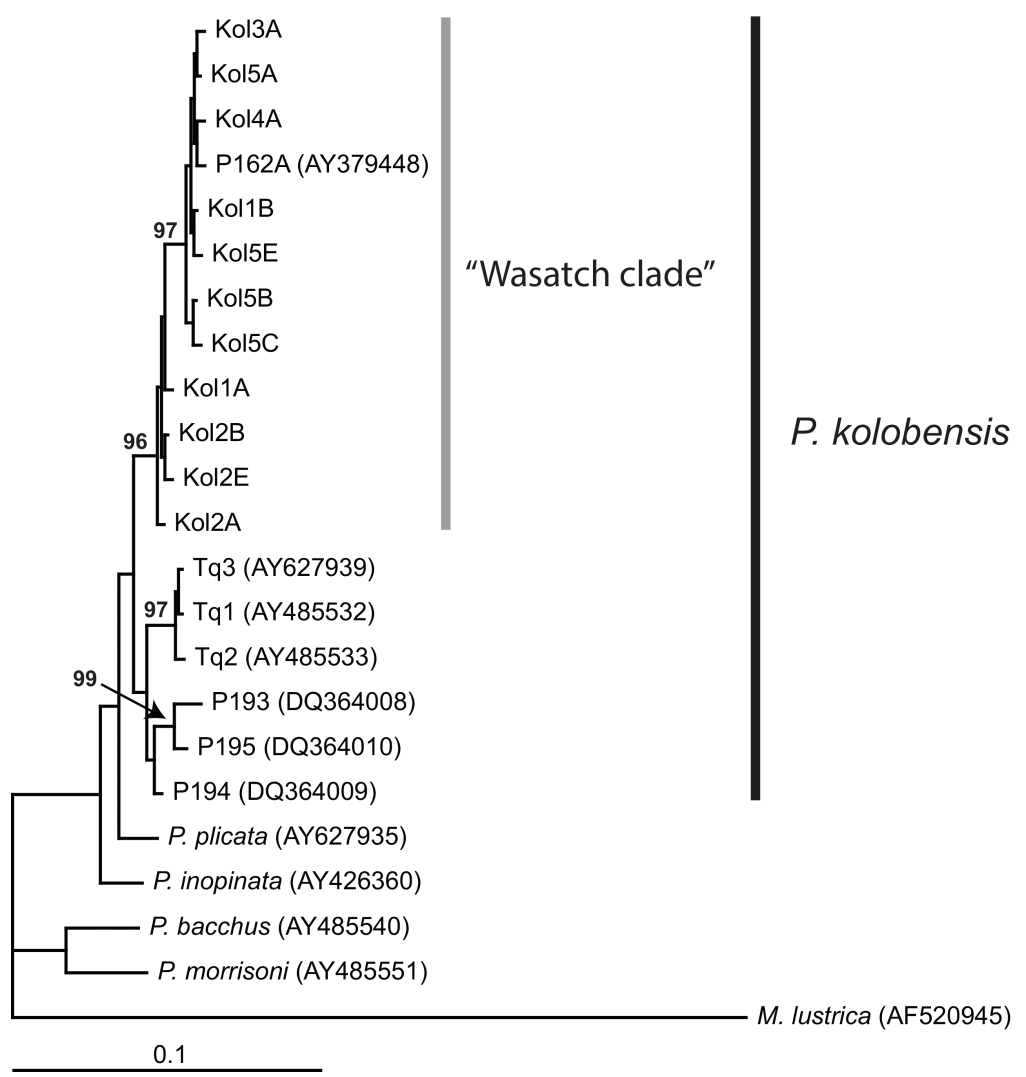

Fig. 2. Bayesian tree based on the COI data set. Specimen codes are from Table 1. GenBank accession numbers are given in parentheses. Posterior probabilities are provided when $>95 \%$.

TABLE 3. Mean (percent) COI sequence divergence within and among Pyrgulopsis kolobensis samples based on uncorrected p-distance (calculated in MEGA6).

\begin{tabular}{|c|c|c|c|c|c|c|c|c|c|}
\hline & Koll & Kol2 & Kol3 & Kol4 & Kol5 & P162 & $\mathrm{Tq}$ & P193 & P194 \\
\hline Koll & $0.3 \pm 0.1$ & & & & & & & & \\
\hline Kol2 & $0.3 \pm 0.1$ & $0.1 \pm 0.1$ & & & & & & & \\
\hline Kol3 & $0.8 \pm 0.3$ & $0.8 \pm 0.3$ & $0.0 \pm 0.0$ & & & & & & \\
\hline Kol4 & $0.8 \pm 0.3$ & $0.8 \pm 0.3$ & $0.3 \pm 0.2$ & $0.0 \pm 0.0$ & & & & & \\
\hline Kol5 & $0.7 \pm 0.3$ & $0.8 \pm 0.3$ & $0.3 \pm 0.2$ & $0.3 \pm 0.2$ & $0.2 \pm 0.1$ & & & & \\
\hline P162 & $0.8 \pm 0.3$ & $0.8 \pm 0.3$ & $0.3 \pm 0.2$ & $0.3 \pm 0.2$ & $0.3 \pm 0.2$ & $0.0 \pm 0.0$ & & & \\
\hline $\mathrm{Tq}$ & $2.3 \pm 0.6$ & $2.1 \pm 0.5$ & $2.8 \pm 0.6$ & $2.6 \pm 0.6$ & $2.7 \pm 0.6$ & $2.8 \pm 0.6$ & & & \\
\hline P193 & $2.4 \pm 0.6$ & $2.1 \pm 0.5$ & $2.9 \pm 0.6$ & $2.6 \pm 0.6$ & $2.6 \pm 0.6$ & $2.9 \pm 0.6$ & $2.9 \pm 0.5$ & & \\
\hline P194 & $1.3 \pm 0.4$ & $1.1 \pm 0.4$ & $1.8 \pm 0.5$ & $1.8 \pm 0.5$ & $1.7 \pm 0.5$ & $1.8 \pm 0.5$ & $1.3 \pm 0.4$ & $1.5 \pm 0.5$ & \\
\hline P195 & $1.9 \pm 0.5$ & $1.7 \pm 0.5$ & $2.4 \pm 0.6$ & $2.4 \pm 0.6$ & $2.2 \pm 0.5$ & $2.4 \pm 0.6$ & $2.0 \pm 0.5$ & $1.1 \pm 0.4$ & $1.1 \pm 0.4$ \\
\hline
\end{tabular}

(52\% posterior probability) clade in the Bayesian tree within which the haplotypes detected in samples from along the Wasatch Mountains and Bear River drainage formed a well-supported (96\% posterior probability) subunit that we informally referred to herein as the "Wasatch clade" (Fig. 2). The mean sequence divergence among samples in the
Wasatch clade ranged from $0.3 \%$ to $0.8 \%$, whereas divergence among all $P$. kolobensis samples ranged from $0.3 \%$ to $2.9 \%$ (Table 3 ).

\section{Discussion}

Our finding of shallow phylogeographic structure of $P$. kolobensis across the Wasatch 
divide obviously does not support the hypothesis of subdivision (vicariance) coincident with the tectonic development of the Wasatch Mountains, nor does it support a hypothesis that this range separates distantly related lineages. The mean sequence divergence between the Strawberry Valley and other $P$. kolobensis samples ranged from $0.3 \%$ to $0.8 \%$ (Table 3), which suggests that divergence occurred about 494,000-185,000 years ago (well postdating uplift of the Wasatch Range) based on a geology calibrated COI clock for Pyrgulopsis (1.62\% of substitutions per million years; Hershler and Liu 2008). This result is consistent with the headwater transfer hypothesis outlined above, although the geologic evidence for this drainage displacement has not been spelled out in detail in the literature, nor is it well constrained chronologically. Although our findings indicate that the Strawberry Valley lineage diverged well prior to historic times, we cannot entirely rule out the possibility of a recent introduction given our incomplete sampling along the western side of the Wasatch divide (Fig. 1). However, we note in this context that there have been no confirmed reports of introduced springsnails anywhere in the West to date (Hershler et al. 2014a). Additional population sampling and use of more rapidly evolving molecular markers will be needed to discriminate between these 2 completing hypothesis for recent divergence across the Wasatch divide.

The phylogeographic pattern detailed herein bears some similarity to that previously reported for another regional caenogastropod, Fluminicola coloradensis, although the latter appears to have spread across the Wasatch divide somewhat farther to the north (fig. 1 in Liu et al. 2013). These findings provide an interesting contrast with fishes, which in most cases have failed to cross the Wasatch barrier (Smith 1978) despite their far greater mobility. The ability of these 2 snail species to penetrate into upland headwater habitats (coldwater streams and springs) appears to be the key to their success in crossing the Wasatch (and other) drainage divides.

\section{ACKNOWLEDGMENTS}

This project was supported in part by an award to HPL from LAS Mini-Grant, Metropolitan State University of Denver.

\section{Literature Cited}

Bryant, B., C.W. Naeser, R.F. Marvin, and H.H. Mehnert. 1989. Ages of late Paleogene and Neogene tuffs and the beginning of rapid regional extension, eastern boundary of the Basin and Range province near Salt Lake City, Utah. United States Geological Survey Bulletin 1787:K1-K12.

BuCKLIN, A. 1992. Use of formalin-preserved samples for molecular analysis. Newsletter of Crustacean Molecular Techniques 2:3.

Folmer, O., M. Black, W. Hoeh, R. Lutz, and R. VrijenHOEK. 1994. DNA primers for amplification of mitochondrial cytochrome $c$ oxidase subunit I from diverse metazoan invertebrates. Molecular Marine Biology and Biotechnology 3:294-299.

Hasegawa, M., H. Kishino, and T. Yano. 1985. Dating the human-ape split by a molecular clock of mitochondrial DNA. Journal of Molecular Evolution 22: 160-174.

Hershler, R. 1998. A systematic review of the hydrobiid snails (Gastropoda: Rissooidea) of the Great Basin, western United States. Part I. Genus Pyrgulopsis. Veliger 41:1-132.

Hershler, R., AND H.-P. LiU. 2004a. Taxonomic reappraisal of species assigned to the North American freshwater gastropod subgenus Natricola (Rissooidea: Hydrobiidae). Veliger 47:66-81.

Hershler, R., AND H.-P. Liu. 2004b. A molecular phylogeny of aquatic gastropods provides a new perspective on biogeographic history of the Snake River region. Molecular Phylogenetics and Evolution 32: 927-937.

Hershler, R., AND H.-P. LiU. 2008. Ancient vicariance and recent dispersal of springsnails (Hydrobiidae: Pyrgulopsis) in the Death Valley system, CaliforniaNevada. Pages 91-101 in M.C. Reheis, R. Hershler, and D.M. Miller, editors, Late Cenozoic drainage history of the southwestern Great Basin and lower Colorado River region: geologic and biotic perspectives. Geological Society of America Special Paper 439. dx.doi.org/10.1130/2008.2439(04)

Hershler, R., H.-P. Liu, ANd C. Bradford. 2013. Systematics of a widely distributed western North American springsnail, Pyrgulopsis micrococcus (Caenogastropoda, Hydrobiidae), with descriptions of three new congeners. ZooKeys 330:27-52.

Hershler, R., H.-P. LiU, and J. Howard. 2014 a. Springsnails: a new conservation focus in western North America. BioScience 64:693-700.

Hershler, R., V. Ratcliffe, H.-P. Liu, B. Lang, and C. Hay. 2014b. Taxonomic revision of the Pyrgulopsis gilae (Caenogastropoda: Hydrobiidae) species complex, with descriptions of two new species from the Gila River basin. ZooKeys 429:69-85.

Hopken, M.W., M.R. Douglas, and M.E. Douglas. 2013. Stream hierarchy defines riverscape genetics of a North American desert fish. Molecular Ecology 22:956-971.

HuElsenbeck, J.P., AND F. RoNQUist. 2001. MRBAYES: Bayesian inference of phylogeny. Bioinformatics 17:754-755.

HuRT, C.R. 2004. Genetic divergence, population structure and historical demography of rare springsnails (Pyrgulopsis) in the lower Colorado River basin. Molecular Ecology 13:1173-1187. 
La Rue, E.C. 1916. Colorado River and its utilization. United States Geological Survey Water-Supply Paper 395:1-231 + plates.

Lentsch, L.D., C.W. Thompson, and R.L. Spateholts. 2001. Overview of a large-scale chemical treatment success story: Strawberry Valley, Utah. Pages 63-79 in R.L. Cailteux, L. DeMong, B.J. Finlayson, W. Horton, W. McClay, R.A. Schnick, and C. Thompson, editors, Rotenone in fisheries: are the rewards worth the risks? American Fisheries Society, Trends in Fisheries Science and Management 1, Bethesda, MD.

LiU, H.-P., AND R. Hershler. 2005. Molecular systematics and radiation of western North American nymphophiline gastropods. Molecular Phylogenetics and Evolution 34:284-298.

Liu, H.-P., R. Hershler, and F.G. Thompson. 2001. Phylogenetic relationships of the Cochliopinae (Rissooidea: Hydrobiidae): an enigmatic group of aquatic gastropods. Molecular Phylogenetics and Evolution 21: $17-25$.

LiU, H.-P., J. Walsh, and R. Hershler. 2013. Taxonomic clarification and phylogeography of Fluminicola coloradensis Morrison, a widely ranging western North American pebblesnail. Monographs of the Western North American Naturalist 6:87-110.

Loxterman, J.L., and E.R. KeELey. 2012. Watershed boundaries and geographic isolation: patterns of diversification in cutthroat trout from western North America. BMC Evolutionary Biology 12:38.

Nelson, A.R., AND C.K. Krinsky. 1982. Late Cenozoic history of the upper Weber and Provo Rivers, N.E. Utah. Geological Society of America Abstracts with Programs 14(6):344.

NELSON, S.R, EDITOR. 1997. History of the Uinta National Forest, a century of stewardship. United States Department of Agriculture, Forest Service, Uinta National Forest, Provo, UT; [accessed November 2014]. http:// www.fs.usda.gov/Internet/FSE_DOCUMENTS/fsem 035417.pdf
NylandeR, J.A.A. 2004. MrModeltest v2. [Program distributed by the author.] Evolutionary Biology Centre, Uppsala University.

OAKey, D.D., M.E. Douglas, and M.R. Douglas. 2004. Small fish in a large landscape: diversification of Rhinichthys osculus (Cyprinidae) in western North America. Copeia 2004:207-221.

SigLER, W.F., AND J.W. SigLER. 1996. Fishes of Utah, a natural history. University of Utah Press, Salt Lake City, UT.

Sмiтн, G.R. 1978. Biogeography of Intermountain fishes. Great Basin Natural Memoirs 2:17-42.

Smith, G.R., AND T.E. Dowling. 2008. Correlating hydrographic events and divergence times of speckled dace (Rhinichthys: Teleostei: Cyprinidae) in the Colorado River drainage. Pages 301-317 in M.C. Reheis, R. Hershler, and D.M. Miller, editors, Late Cenozoic drainage history of the southwestern Great Basin and lower Colorado River region: geologic and biotic perspectives. Geological Society of America Special Paper 439. dx.doi.org/10.1130/2008.2439(13)

Sullivan, J.T., A.R. Nelson, R.C. LaForge, C.K. Wood, and R.A. Hansen. 1988. Central Utah regional seismotectonic study for USBR dams in the Wasatch Mountains. Seismotectonic Report 88-5, United States Bureau of Reclamation, Denver, CO; [accessed November 2014]. http://geology.utah.gov/online/mp/ mp11-02/88-5.pdf

Tamura, K., G. Stecher, D. Peterson, A. Filipski, and S. Kumar. 2013. MEGA6: molecular evolutionary genetics analysis version 6.0. Molecular Biology and Evolution 30:2725-2729.

VInSON, M. 2004. The occurrence and distribution of New Zealand mud snail (Potamopyrgus antipodarum) in Utah. Final report for Utah Department of Natural Resources, Division of Wildlife Resources, Salt Lake City, UT.

Received 7 January 2015 Accepted 16 June 2015 